\title{
CLEAN ENERGY SOLUTIONS CENTER SERVICES
}

The Clean Energy Solutions Center helps governments, advisors and analysts create policies and programs that advance the deployment of clean energy technologies. Through its no cost offerings, the Solutions Center enables countries to learn from and share policy best practices, data and analysis tools, creating an international dialogue on clean energy policies that raises global awareness of emerging policy issues and innovations.

\section{Existing Users of Ask an Expert Service}

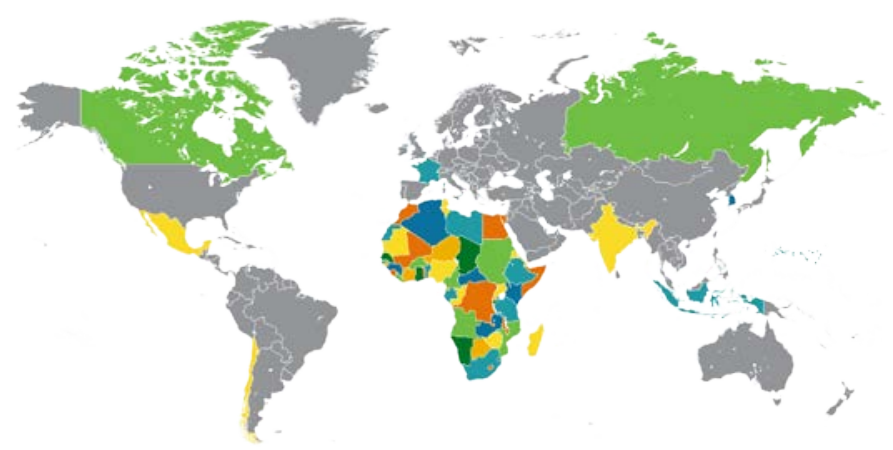

\section{ASK AN EXPERT}

As part of these efforts, the Solutions Center provides an indispensable service by connecting those seeking policy information and advice with policy experts who can help them achieve their goals. The Solutions Center's Ask an Expert service matches policymakers with one of the more than 30 global experts selected as authoritative leaders on specific clean energy policy topics.

\section{Who is eligible?}

Clean energy policy support is available to representatives of government agencies and any technical institutes assisting governments.

\section{How to Request Assistance}

To request expert assistance from the Clean Energy Solutions Center:

1. Submit your question at cleanenergysolutions.org/expert.

2. Complete the registration information.

3. Choose your policy topic(s).

The Solutions Center will initiate a conversation with registered users within two days to learn more about your needs and match you with the appropriate expert to assist you.

\section{How does the Solutions Center help?}

The Solutions Center can assist policymakers with many types of clean energy policy, including development of strategies, regulations and standards, financial incentives and deployment programs. Solutions Center experts can review drafts of measures and strategies, conduct research, share best practices from other countries, and engage in consultations by phone and email. Support is limited to remote assistance and clean energy policy topics. The Solutions Center does not provide assistance with project development or technology and system assessment.

\section{When can I expect a response?}

The Solutions Center will initiate a conversation with registered users within two days, providing policy assistance via phone and email consultations.

\section{A SUCCESSFUL TRACK RECORDWITH DIVERSE POLICIES}

Since Ask an Expert launched in 2012, its experts have responded to more than 75 requests for assistance. This assistance has included evaluations of policies and programs to advance the use of energy efficiency and renewable energy technologies; enhance energy access; and address other municipal, state, and national clean energy objectives.

\section{Assisting the Republic of Trinidad and Tobago}

The Trinidad and Tobago Ministry of Energy and Energy Affairs asked the Solutions Center to provide assistance to the Caribbean Community (CARICOM) on sustainable energy planning and implementation strategy. A Solutions Center expert delivered advice and engaged in consultations on the interaction of feed-in tariffs and net billing, and the adoption of regional and national sustainable energy targets. The expert also commented on proposed plans for transmission interconnection between member states. Thirteen member states finalized and ratified the draft CARICOM energy policy during the 41st Special Meeting of the Council for Trade and Economic Development. The energy policy will now be submitted to the respective governments for cabinet approval.

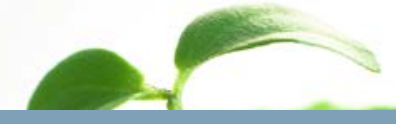




\section{EXPERTS}

The Solutions Center has selected more than 30 global experts as authoritative leaders on specific clean energy policy topics. Experts have tackled diverse topics in critical areas such as energy efficiency, renewable energy, transportation, energy access, regulatory issues and integrated planning.

\begin{tabular}{|l|l|l|}
\hline Antonia Gawel, Independent Consultant & $\begin{array}{l}\text { Ibrahim Rehman, The Energy and Resources } \\
\text { Institute }\end{array}$ & $\begin{array}{l}\text { Paul Komor, University of Colorado at Boulder, } \\
\text { Renewable and Sustainable Energy Institute }\end{array}$ \\
\hline Barbara Buchner, Climate Policy Initiative & Jane Wilkinson, Climate Policy Initiative & Qi Ye, Independent Consultant \\
\hline Bertrand Chateau, Enerdata & Jeff Deason, Climate Policy Initiative & Riley Allen, Regulatory Assistance Project \\
\hline Bruno Lapillonne, Enerdata & John Wright, Wright Energy Consulting & Steve Schuck, Bioenergy Australia \\
\hline Cesar Trevino, Mexico Green Building Council & $\begin{array}{l}\text { Joseph Essandoh-Yeddu, Ghana Energy } \\
\text { Commission }\end{array}$ & $\begin{array}{l}\text { Ted Sears, National Renewable Energy } \\
\text { Laboratory }\end{array}$ \\
\hline Chad Laurent, Meister Consultants Group & Julia Reinaud, Institute for Industrial Productivity & Terri Walters, Katevan Consulting \\
\hline $\begin{array}{l}\text { Christine Egan, Collaborative Labeling and } \\
\text { Appliance Standards Program }\end{array}$ & $\begin{array}{l}\text { Karlynn Cory, National Renewable Energy } \\
\text { Laboratory }\end{array}$ & Thomas Heller, Climate Policy Initiative \\
\hline $\begin{array}{l}\text { David Jacobs, Institute of Advanced } \\
\text { Sustainability Studies }\end{array}$ & Kurt Shickman, Global Cool Cities Alliance & Uday Varadarajan, Climate Policy Initiative \\
\hline David Nelson, Climate Policy Initiative & $\begin{array}{l}\text { Luis Crespo, European Solar Thermal Electricity } \\
\text { Association }\end{array}$ & William Becker, Independent Consultant \\
\hline Ellen Morris, Sustainable Energy Solutions & $\begin{array}{l}\text { Morgan Hervé-Mignucci, Climate Policy Initiative } \\
\text { Olivier Dubois, United Nations Food and } \\
\text { Agriculture Organization }\end{array}$ & Wilson Rickerson, Meister Consultants Group \\
\hline G.C. Datta Roy, Dalkia-India & $\begin{array}{l}\text { Xavier Lemaire, Sustainable Energy Regulation } \\
\text { Network }\end{array}$ & \\
\hline $\begin{array}{l}\text { Gustau Mañez Gomis, United Nations } \\
\text { Environment Programme }\end{array}$ & & \\
\hline
\end{tabular}

\section{PARTNERSHIPS WITH INTERNATIONAL ORGANIZATIONS}

The Ask an Expert service draws on international partnerships and collaborations to deliver assistance.

- Leonardo Energy

- United Nations Environment Programme

- The International Renewable Energy Agency (IRENA)

- The International Partnership for Energy Efficiency Cooperation (IPEEC)

- Low Emission Development Strategies (LEDS) Global Partnership, or LEDS GP

- United Nations Food and Agriculture Organization
- United Nations Sustainable Energy for All (SE4ALL)

- 21st Century Power Partnership

- ClimateWorks Foundation

- Climate Policy Initiative

- Enerdata

\section{ABOUT THE CLEAN ENERGY SOLUTIONS CENTER}

The Solutions Center serves as a first-stop clearinghouse of clean energy policy reports, data and tools, and provides interactive expert assistance and training forums. The Solutions Center is an initiative of the Clean Energy Ministerial (CEM), a global forum to share best practices and promote policies and programs that encourage and facilitate the transition to a global clean energy economy. The Solutions Center also receives support from a unique partnership with UN-Energy, the United Nations' interagency mechanism to scale-up global clean energy use.

To learn more about the Solutions Center and how its Ask an Expert service can assist you in achieving your policy goals, please visit www.cleanenergysolutions.org/expert.
Illustration from iStock, 15639353

NREL/FS-6A20-58270 • May 2013

Printed with a renewable-source ink on paper containing at least $50 \%$ wastepaper, including $10 \%$ post consumer waste. 